\title{
Vertical distribution of zooplankton after rapid change in temperature and chlorophyll concentration
}

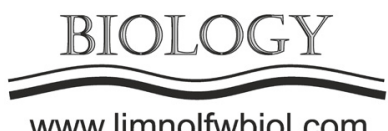

www.limnolfwbiol.com

\author{
Makarov M.M.*, Kucher K.M., Naumova E.Yu. \\ Limnological Institute, Siberian Branch of the Russian Academy of Sciences, Ulan-Batorskaya Str., 3, Irkutsk, 664033, Russia
}

\begin{abstract}
In October 2018, after the change in the temperature profile and chlorophyll concentration, we recorded the changes in the distribution parameters of mesozooplankton in the surface $100 \mathrm{~m}$ layer at the station located in the pelagic zone of Lake Baikal. The study was carried out on horizons of 0-50 and 50-100 m. Measurements were performed using an AAQ-Rinko water quality probe (JFE, Japan), a SBE-25 CTD probe (SeaBirdElectronics, USA) and a Furuno FCV-1100 sonar (Furuno, Japan). We found a deepening of zooplankton after the immersion of the chlorophyll and temperature maximum.
\end{abstract}

Keywords: Lake Baikal, chlorophyll, zooplankton, contemporary approaches, water quality probe, sonar

\section{Introduction}

Plankton is a complex three-dimensional system, which rapidly changes with time. The changes depend on physical and chemical factors that are daily, seasonal, etc. The vertical distribution of zooplankton is associated with the changes in biological parameters: the food volume and the presence of predators. Zooplankton itself affects the environment, consuming algae and returning nutrients to the environment, as well as changes the existence conditions of phyto- and bacterioplankton. Many aspects of this issue have not been yet understood for Lake Baikal: the formation of the zooplankton microlayers, environmental implication of stratification and turbulent mixing (Melnik et al., 2008; Hampton et al., 2014). Due to global climate change, ecological monitoring programs for large lakes should combine high spatial and temporal resolution of data collection, which requires innovative instruments and contemporary approaches (Hampton, 2013; Izmest'eva et al., 2016).

Instrumental methods for studying zooplankton allow almost real-time tracking of the changes in the vertical and horizontal distribution and state. Additionally, conventional net and bathometer sampling followed by laboratory processing can supplement the accurate data on the quality and quantity of planktonic organisms. Thus, it is possible to create an accurate picture in almost real time scale.

The aim of this study was to correlate the rapidly changing environmental factors with the behaviour of zooplankton.

\section{Material and methods}

The study was carried out near Cape Berezovy, Southern Baikal, at a depth of $1338 \mathrm{~m}$ on October 11 and 19, $2018\left(51,7849^{\circ} \mathrm{N} ; 104,9329^{\circ} \mathrm{E}\right)$. Time was 17:00-19:00. Water temperature, chlorophyll, photosynthetically active radiation and other parameters were measured with a AAQ-Rinko probe. The Table 1 shows the probe specifications in detail.

In addition to the AAQ-Rinko data, we had access to the data from SBE-25 CTD-probe, which was used at the same stations with a delay of 5-10 minutes. The hydroacoustic survey was performed with an upgraded FCV-1100 sonar. The sonar was configured as follows: signal frequency $-28 \mathrm{kHz}$, the pulse repetition rate $5 \mathrm{~Hz}$ and the pulse duration $-0.3 \mathrm{~ms}$. The $3 \mathrm{~dB}$ beam width of the single beam hydroacoustic transducer was $12^{\circ}$. Mesozooplankton were sampled with Juday net of $88 \mu \mathrm{m}$ mesh size (open diameter $35,7 \mathrm{~cm}$ ) at $0-50$, $50-100 \mathrm{~m}$, fixed in $4 \%$ formalin and counted under a light microscope after concentration by sedimentation.

\section{Results and discussion}

The temperature profile obtained using the SBE-25 probe correlates well with the hydroacoustic survey data. Within the depth range of $100-150 \mathrm{~m}$, there are sound scattering layers (SLs) resulted from an abrupt decrease in temperature by $3^{\circ} \mathrm{C}$, from 7.5 to $4.5^{\circ} \mathrm{C}$.

Figure 1 shows the data on the hydroacoustic survey and CTD profiling up to a depth of $110 \mathrm{~m}$, which 
Table 1. AAQ-Rinko probe instrument specifications

\begin{tabular}{|c|c|c|c|c|}
\hline Measured parameter & Measurement range & Resolution & Accuracy & \begin{tabular}{|c}
$\begin{array}{c}\text { Response } \\
\text { time }\end{array}$ \\
\end{tabular} \\
\hline Depth & $0-100 \mathrm{~m}$ & $0.002 \mathrm{~m}$ & $\pm 0.3 \%$ of full scale & $0.2 \mathrm{~s}$. \\
\hline Water temperature & $-3-45^{\circ} \mathrm{C}$ & $0.001{ }^{\circ} \mathrm{C}$ & $\pm 0.01{ }^{\circ} \mathrm{C}\left(0-35^{\circ} \mathrm{C}\right)$ & $0.2 \mathrm{~s}$. \\
\hline Electrical conductivity & $0-2000 \mu \mathrm{S} \mathrm{cm}$ & $0.1 \mu \mathrm{S} \mathrm{cm}{ }^{-1}$ & $\pm 2 \mu \mathrm{S} \mathrm{cm}^{-1}\left(0\right.$ to $\left.200 \mu \mathrm{S} \mathrm{cm}^{-1}\right)$ & $0.2 \mathrm{~s}$. \\
\hline Suspended matter & 0 - 1,000 FTU & 0.03 FTU & \pm 0.3 FTU or $\pm 2 \%$ & $0.2 \mathrm{~s}$. \\
\hline Chlorophyll & $0-400 \mathrm{mgm}^{-3}$ & $0.01 \mathrm{mgm}^{-3}$ & $\pm 1 \%$ of full scale & $0.2 \mathrm{~s}$ \\
\hline Dissolved oxygen & $0-20 \mathrm{mgL}^{-1}(0-200 \%)$ & $0.001-0.004 \mathrm{mg} \mathrm{L}^{-1}$ & $\pm 0.4 \mathrm{mg} \mathrm{L}^{-1}( \pm 2 \%$ of full scale $)$ & $0.4 \mathrm{~s}$. \\
\hline $\begin{array}{l}\text { Photosynthetically active } \\
\text { radiation in water }\end{array}$ & $0-5,000 \mu \mathrm{molm}^{-2} \mathrm{~s}^{-1}$ & $0.1 \mu$ molm $^{-2} \mathrm{~s}^{-1}$ & $\pm 4 \%$ & $0.2 \mathrm{~s}$. \\
\hline $\mathrm{pH}$ value & $2-14 \mathrm{pH}$ & $0.01 \mathrm{pH}$ & $\pm 0.2 \mathrm{pH}$ & $10 \mathrm{~s}$. \\
\hline $\begin{array}{l}\text { Oxidation / reduction } \\
\text { potential }\end{array}$ & $0- \pm 1,000 \mathrm{mV}$ & $0.1 \mathrm{mV}$ & - & $10 \mathrm{~s}$. \\
\hline
\end{tabular}

were performed on October 11, 2018. A week later (October 19, 2018), we performed a second survey at this site. There was windy weather for several days, which caused the intense mixing of the upper 100-meter water layer (see Fig. 2). The temperature rise remained at the same depth. There were no significant SLs.

The average temperature of the surface 20 -meter layer was $8-8.5^{\circ} \mathrm{C}$, which decreased to $7.5^{\circ} \mathrm{C}$ at a depth of $100 \mathrm{~m}$. After the mixing, we observed (Fig. 1) the immersion of the layer with a temperature of approximately $8^{\circ} \mathrm{C}$ up to $70 \mathrm{~m}$. Below, the temperature of approximately $7.5^{\circ} \mathrm{C}$ remained.

In oligotrophic water bodies and in Baikal Lake, there is a high correlation between the vertical distribution of chlorophyll and temperature (Hampton et al., 2008; Watkins et al., 2015; Shimaraeva et al., 2017) In the surface layer, chlorophyll a varied significantly (0.58-5.3 mg $/ \mathrm{m}^{3}$ ) in July 2018 (Churilova et al., 2018). We could observe a maximum of chlorophyll in the $0-20$ $\mathrm{m}$ layer with a concentration of $1.2 \mathrm{mg} / \mathrm{m}^{3}$. Below 50 $\mathrm{m}$, we observed an abrupt decrease in the concentration to $0.7 \mathrm{mg} / \mathrm{m}^{3}$ and an increase in the concentration to $0.8 \mathrm{mg} / \mathrm{m}^{3}$ at a depth of $90 \mathrm{~m}$. After mixing, the picture changed, and the concentration gradually decreased from $1.1 \mathrm{mg} / \mathrm{m}^{3}$ in the surface layer to $0.8 \mathrm{mg} / \mathrm{m}^{3}$ in the layer below $70 \mathrm{~m}$.

Normally, in autumn three groups play the main role in zooplankton of the Baikal pelagic zone: Copepoda, Cladocera and Rotifera. The copepods Epischura baikalensis Sars and Cyclops kolensis Lilljeborg are almost constant habitants here (Mazepova, 1998; Melnik et al., 1998). The fauna of rotifers in open waters is mostly based on paleo- and Holarctic species, which are widespread in lakes of northern latitudes. They form two ecological groups of rotifers, all-season and summer-autumn ones. The first group includes Keratella quadrata (Müller), K. cochlearis (Gosse), Kellicottia longispina (Kellicott) and Filinia terminalis Plate. The second group includes 19 species and has a very variable species composition in different years. Endemic species form the third ecological group, spring rotifers, which occur only from December to June-July.

In our samples, there were $E$. baikalensis and $C$. kolensis from the Copepoda group. Bosmina longirostris (O.F.Müller) was the only representative of Cladocera in the pelagic plankton. All-season rotifers were found
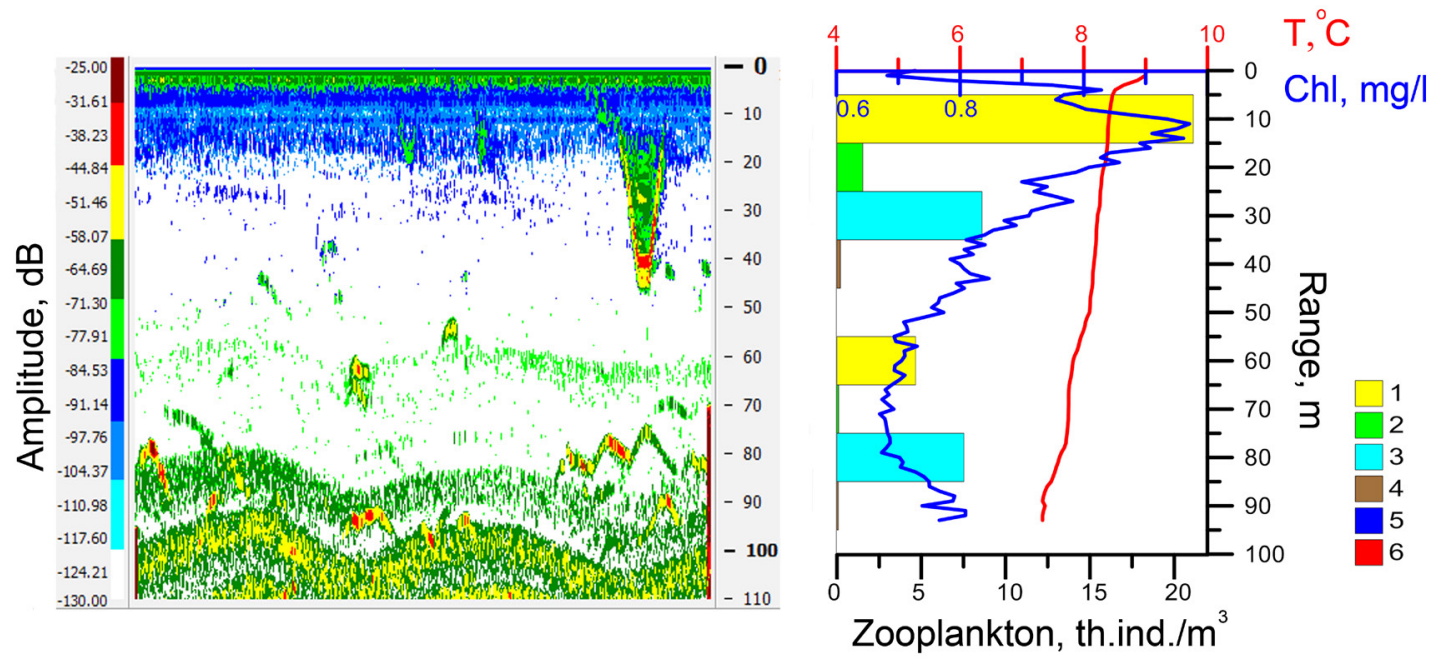

Fig. 1. Echogram, temperature and chlorophyll profile, zooplankton concentration obtained in $3 \mathrm{~km}$ from Cape Berezovy on October 11, 2018. 1- All-season Rotifera; 2- Summer Rotifera; 3- Copepoda; 4- Cladocera; 5- Chlorophyll; 6- Temperature 

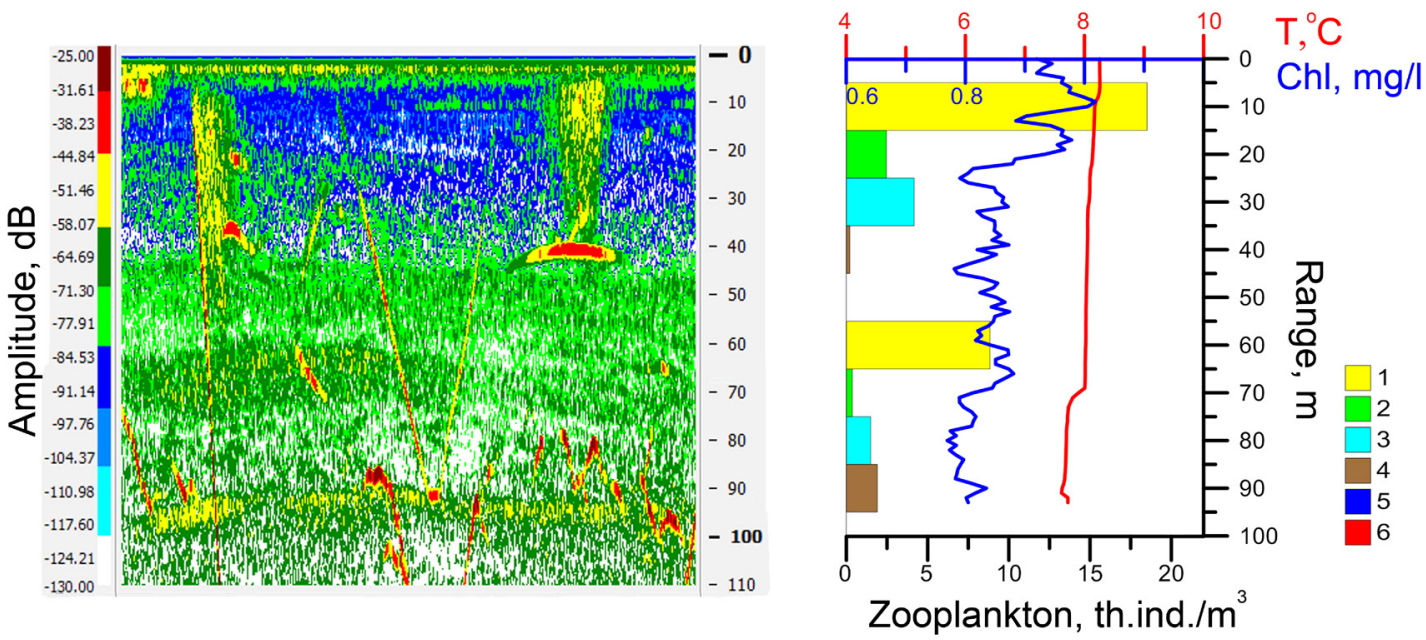

Fig. 2. Echogram, temperature and chlorophyll profile, zooplankton concentration obtained in $3 \mathrm{~km}$ from Cape Berezovy on October 19, 2018

in all samples. The number and species composition of summer-autumn rotifers were higher on October 11. Thus, the samples contained: Bipalpus hudsoni (Imhof), Synchaeta stylata Wierzejski, Synchaeta grandis Zacharias, Collotheca sp.sp., Lecane(M) lunaris (Ehrenberg), Asplanchna priodonta Gosse, Polyarthra dolichoptera Idelson, and Trichocerca capucina (Wierzejski et Zacharias).

On October 11, in the upper $50 \mathrm{~m}$ layer epishura dominated mesozooplankton (Table 2). The plankton contained all age stages, but copepodite stages 4 and 5 , as well as nauplius stages 4 and 5 prevailed. The number of Bosmina longirostris reached 0.2 thousand ind. $/ \mathrm{m}^{3}$ in the surface layer and 0.09 thousand ind. $/ \mathrm{m}^{3}$ in the layer below $50 \mathrm{~m}$. Keratella quadrata and Filinia terminalis dominated rotifers. The total number of $C$. kolensis was up to 0.4 thousand ind. $/ \mathrm{m}^{3}$ in the surface layer, where rotifers and cladocerans concentrated. Below $50 \mathrm{~m}$, the zooplankton concentration decreased. The age structure of epishura changed. In this layer, nauplius stages 3 and 4 prevailed. Therefore, most of the copepodite stages of epishura and C. kolensis were in the layer of the maximum chlorophyll. The surface layer also contained $74 \%$ of the total number of all-season rotifers and $91 \%$ of the total number of summer-autumn ones.
After wind mixing, on October 19 the zooplankton concentration in the surface layer decreased. Epishura nauplius stages 3 - 5 and copepodite stages 4 and 5 predominated near the surface. Bosmina longirostris was 0.2 thousand ind. $/ \mathrm{m}^{3}$ in the surface layer and 0.2 thousand ind. $/ \mathrm{m}^{3}$ below $50 \mathrm{~m}$. The number of rotifers remained almost the same near the surface. They were represented by all-season complex and $S$. stylata together with $S$. grandis ( 2.5 thousand ind. $/ \mathrm{m}^{3}$ ). Below $50 \mathrm{~m}$, epishura nauplius stages 3 and 4 and copepodite stages 1 and 2 predominated. The composition of rotifers was the same as in the surface layer. In the distribution of epishura, adult specimens and copepodites deepen in the layer of $50-100 \mathrm{~m}$. At the same time, they are very likely to be found in a significant number below $100 \mathrm{~m}$ from the surface. This may explain the overall decrease in zooplankton biomass in the surface layers after mixing and immersion of the high temperature and chlorophyll layer. During the autumn overturn the chlorophyll $a$ reached depths $200 \mathrm{~m}$ (Fietz et al., 2005).

The total zooplankton number in the layer of 0-100 $\mathrm{m}$ before and after mixing was almost the same (19.7 and 19.1 thousand ind. $/ \mathrm{m}^{3}$, respectively). At the same time, the biomass decreased by $42 \%$. We assume that this was due to the deepening of the crustaceans to a layer below $100 \mathrm{~m}$.

Table 2. Abundance and biomass of zooplankton at the station $3 \mathrm{~km}$ from Cape Berezovy

\begin{tabular}{|c|c|c|c|c|}
\hline & \multicolumn{2}{|c|}{ October 11, 2018} & \multicolumn{2}{|c|}{ October 19, 2018} \\
\hline & $0-50 \mathrm{~m}$ & $50-100 \mathrm{~m}$ & $0-50 \mathrm{~m}$ & $50-100 \mathrm{~m}$ \\
\hline Zooplankton number, thousand ind. $/ \mathrm{m}^{3}$ & 31.5 & 12.5 & 25.47 & 13.1 \\
\hline Zooplankton biomass, $\mathrm{mg} / \mathrm{m}^{3}$ & 225.5 & 84.4 & 102.0 & 61.3 \\
\hline Epishura nauplii number, thousand ind. $/ \mathrm{m}^{3}$ & 2.1 & 6.0 & 1.3 & 1.5 \\
\hline Epishura nauplii biomass, $\mathrm{mg} / \mathrm{m}^{3}$ & 8.9 & 23.9 & 5.5 & 5.8 \\
\hline Number of epishura copepodite stages $1-6$, thousand ind. $/ \mathrm{m}^{3}$ & 6.2 & 1.5 & 2.6 & 2.0 \\
\hline Biomass of epishura copepodite stages $1-6, \mathrm{mg} / \mathrm{m}^{3}$ & 198.8 & 55.2 & 77.9 & 47.6 \\
\hline Total number of rotifers, thousand ind. $/ \mathrm{m}^{3}$ & 22.7 & 4.8 & 21.0 & 9.2 \\
\hline
\end{tabular}


A high chlorophyll concentration below $50 \mathrm{~m}$ creates an active layer for the formation of primary and secondary products (Twiss et al., 2012). This explains the decrease in the number of zooplankton in the surface $50 \mathrm{~m}$ layer, which takes place in autumn at high chlorophyll concentrations (Kiprushina, 2009; Pislegina, 2013).

\section{Summary}

The preliminary results of complex investigations carried out at Lake Baikal in October 2018 showed that the wind mixing causes an immersion of the layer with a high chlorophyll concentration and a deeper distribution of zooplankton. Temperature can be a marker of the plankton distribution depth. Disregarding the change in patterns of the spatial distribution may lead to an incorrect estimate of the total number of zooplankton and its individual groups. This work allows developing a system for operative (real-time) ecological monitoring.

\section{Acknowledgments}

The study was carried out within the project 03452019-0008 (AAAA-A16-116122110065-4) "Assessment and forecast of ecological status of Lake Baikal and adjacent areas under the anthropogenic stress and the global climate change".

\section{References}

Churilova T.Ya., Moiseeva N.A., Latushkin A.A. et al. 2018. Preliminary results of bio-optical investigations at Lake Baikal. Limnology and Freshwater Biology 1: 58-61. DOI: 10.31951/2658-3518-2018-A-1-58

Fietz S., Kobanova G., Izmest'eva L. et al. 2005. Regional, vertical and seasonal distribution of phytoplankton and photosynthetic pigments in Lake Baikal. Journal of Plankton Research 27: 793-810. DOI: 10.1093/plankt/fbi054

Hampton S.E. 2013. Understanding lakes near and far. Science 342: 815-816.

Hampton S.E., Gray D.K., Izmest'eva L.R. et al. 2014. The rise and fall of plankton: long-term changes in the vertical distribution of algae and grazers in Lake Baikal, Siberia. PLoS ONE 9. DOI: 10.1371/journal.pone.0088920

Hampton S.E., Izmest'eva L.R., Moore M.V. et al. 2008. Sixty years of environmental change in the in the world's largest freshwater lake-Lake Baikal, Siberia. Global Change Biology 14: 1947-1958. DOI: 10.1111/j.1365-2486.2008.01616.x

Izmest'eva L.R., Moore M.V., Hampton S.E. et al. 2016. Lake-wide physical and biological trends associated with warming in Lake Baikal. Journal of Great Lakes Research 42: 6-17. DOI: 10.1016/j.jglr.2015.11.006

Kiprushina K.N. 2009. Seasonal dynamics of the zooplankton vertical distribution in the open part of Southern Baikal (near the Bolshiye Koty settlement). The Bulletin of Irkutsk State University. Series "Biology. Ecology" 2: 39-44. (in Russian)

Mazepova G.F. 1998. The role of copepods in the Baikal ecosystem. Journal of Marine System 15: 113-120. DOI: 10.1016/S0924-7963(97)00065-1

Melnik N.G., Dzyuba E.V., Degtyarev V.A. et al. 2008. Life strategy of pelagic animals in Lake Baikal. Verhandlungen des Internationalen Verein Limnologie [Negotiations of the International Limnology Association] 30: 291-294. DOI: 10.1080/03680770.2008.11902129

Melnik N.G., Sheveleva N.G., Pomazkova G.I. 1998. Distribution of planktonic copepods of Lake Baikal. Journal of Marine System 15: 149-153. DOI: 10.1016/ S0924-7963(97)00074-2

Pislegina E.V. 2013. Biomass dynamics of phytoplankton, epishura and copepods in the years of their maximum abundance in the pelagic zone of Southern Baikal. Izvestiya Irkutskogo Gosudarstvennogo Universiteta. Seriya "Biologiya, Ecologiya" [The Bulletin of Irkutsk State University. Series "Biology. Ecology"] 6: 100-104. (in Russian)

Shimaraeva S.V., Pislegina E.V., Krashchuk L.S. et al. 2017. Dynamics of chlorophyll $a$ concentration in the South Baikal pelagic during the direct temperature stratification period. Inland Water Biology 10: 59-63. DOI: 10.1134/ S1995082917010163

Twiss M.R., Ulrich C., Zastepa A. et al. 2012. On phytoplankton growth and loss rates to microzooplankton in the epilimnion and metalimnion of Lake Ontario in mid-summer. Journal of Great Lakes Research 38: 146-153. DOI: 10.1016/j.jglr.2012.05.002

Watkins J.M., Weidel B.C., Rudstam L.G. etal. 2015. Spatial extent and dissipation of the deep chlorophyll layer in Lake Ontario during the Lake Ontario lower food web assessment, 2003 and 2008. Aquatic Ecosystem Health \& Management 18:18-27. DOI: 10.1080/14634988.2014.937316 